\section{Aplikasi Membran Ultrafiltrasi Termodifikasi untuk Penyediaan Air Bersih Layak Konsumsi di Desa Jambu Burung Kalimantan Selatan}

\section{Agus Mirwan ${ }^{1,3}$ Doni Rahmat Wicakso ${ }^{1,3}$ Abdul Ghofur ${ }^{2}$ Iryanti Fatyasari Nata ${ }^{3}$}

\author{
1 Program Studi Pendidikan Profesi Insinyur, Universitas \\ Lambung Mangkurat \\ 2 Program Studi Teknik Mesin, Universitas Lambung \\ Mangkurat \\ 3 Program Studi Teknik Kimia, Universitas Lambung \\ Mangkurat
}

agusmirwan@ulm.ac.id

\begin{abstract}
Jambu Burung merupakan salah satu desa di wilayah Kecamatan Beruntung Baru Kabupaten Banjar Kalimantan Selatan dengan lingkup wilayah disekitar bantaran sungai dan pesisir pantai yang belum memiliki akses air bersih dari perusahaan daerah air minum. Selama ini, masyarakat terbiasa menggunakan air sungai dan air sumur untuk kebutuhan sehari-hari dengan kondisi masih jauh dari layak untu dikonsumsi. Teknologi membran ultrafiltrasi memiliki beberapa keunggulan diantaranya dapat memisahkan spesifikasi kimia secara spesifik, beroperasi pada suhu ambient, tidak destruktif, hemat energi, dan tidak mencemari lingkungan. Kegiatan ini bertujuan untuk menerapkan teknologi membran ultrafiltrasi termodifikasi untuk menghasilkan air bersih layak konsumsi bagi masyarakat Desa Jambu Burung. Teknologi yang diaplikasikan terdiri dari rangkaian modul membran, empat buah filter sedimen polipropilen, dan pompa sehingga prosesnya sederhana, praktis, mudah dioperasikankan, dan mudah dipindah-tempatkan (mobile). Hasil analisis kualitas air melalui proses membran ultrafiltrasi termodifikasi berdasarkan parameter fisika dan kimia menunjukkan bahwa tidak ada bau, $112 \mathrm{mg} / \mathrm{L}$ total zat padat terlarut (TDS), kekeruhan 2 NTU, warna o,0135 TCu, suhu $27,2{ }^{\circ} \mathrm{C}$, daya hantar listrik $103 \mu \mathrm{s} / \mathrm{cm}, \mathrm{pH}$ 6,74. Sedangkan kesadahan, besi, mangan, zat organik, dan total fosfat, serta total bakteri koliform menunjukkan angka nol dan diartikan semua parameter telah memenuhi baku mutu yang disyaratkan dalam Peraturan Menteri Kesehatan Republik Indonesia nomor 492 tahun 2010.
\end{abstract}

Kata kunci: air sungai, air sumur, air bersih, baku mutu, membran ultrafiltrasi termodifikasi

Diajukan: 30 Mei 2020

Direvisi: 6 Juni 2020

Diterima: 15 Juni 2020

Dipublikasikan online: 17 Juni 2020

\section{Pendahuluan}

Air merupakan kebutuhan dasar yang sangat penting bagi manusia dan makhluk hidup lainnya. Tidak semua daerah mempunyai sumber daya air yang baik. Wilayah pesisir pantai dan pulau-pulau kecil di muara sungai atau di tengah lautan lepas merupakan daerahdaerah yang sangat miskin akan sumber air bersih, sehingga timbul masalah pemenuhan kebutuhan air bersih terutama pada musim kemarau panjang. Kualitas air tanah sangat bergantung dari curah hujan. Pada musim kemarau, air tawar yang berasal dari air hujan sudah tidak tersedia lagi, sehingga air tanah dengan mudah akan terkontaminasi oleh air laut. Pencemaran kualitas air tanah akibat dari kontaminasi air laut disebut intrusi. Ciri adanya intrusi air laut adalah air tanah yang terasa payau atau mengandung kadar garam khlorida dan TDS (Total Dissolved Solid) yang tinggi yaitu
TDS > 3000 ppm, baik air tanahnya maupun air permukaannya (Mirwan, 2009).

Desa Jambu Burung merupakan salah satu desa di wilayah Kecamatan Beruntung Baru Kabupaten Banjar Kalimantan Selatan, yang letaknya disekitar bantaran sungai dengan lingkup wilayah pesisir pantai dan selama ini belum memiliki akses air bersih dari perusahaan daerah air minum (PDAM). Warga Desa selama ini terbiasa menggunakan air sungai dan air sumur yang ada disekitar untuk kebutuhan sehari-hari seperti mencuci, masak, dan bahkan untuk minum. Padahal kondisi sungai dan air sumur masih mengandung padatan tersuspensi yang tinggi, berwarna kecoklatan, $\mathrm{pH}$ agak rendah, dan tingkat kekeruhan (turbidity) yang tinggi, serta diduga telah tercemar, baik oleh bakteri patogen (coliform) maupun logam berat. Hal ini dikarenakan wilayah Desa ini merupakan wilayah bergambut dan bahkan dimusim kemarau kondisi airnya menjadi payau yang disebabkan letak geografi

Cara mensitasi artikel ini:

Mirwan A., Wicakso D.R., Ghofur A., Nata I.F. (2019) Aplikasi teknologi membrane ultrafiltrasi termodifikasi untuk penyediaan air bersih layak konsumsi di Desa Jambu Burung Kalimantan Selatan. Buletin Profesi Insinyur 3(1) 029032 
nya berdekatan dengan laut sehingga mudah terjadi intrusi air laut ke sungai-sungai yang menjadi sumber kebutuhan hidup warga desa.

Berdasarkan penelitian Susanto (2009), memperlihatkan bahwa kondisi sungai yang melewati Kecamatan Aluh-Aluh dan Kecamatan Beruntung Baru telah tercemar, baik secara fisika, kimia, maupun biologi. Hal ini ditunjukan dengan kandungan residu tersuspensi (TSS) antara 2,6 - 13,8 mg/l, jumlah zat padat terlarut (TDS) antara $233,7-1966,7 \mathrm{mg} / \mathrm{l}$, kekeruhan antara 5,07 - 83,2 NTU, pH 3,09-6,45, logam besi (Fe) antara 1,66 - 8,11 mg/l, dan mangan $(\mathrm{Mn})$ antara $0,33-52,3 \mathrm{mg} / \mathrm{l}$. Selain itu, hasil analisis kuantitatif bakteri Coliform berkisar antara 18.000$170.000 \mathrm{MPN} / 100 \mathrm{ml}$ dan Colitinja/Escherichia coli berkisar antara $<180-92000 \mathrm{MPN} / 100 \mathrm{ml}$, yang telah melebihi ambang batas peruntukan dan baku mutu air sungai kelas I berdasarkan Peraturan Gubernur Kalimantan Selatan Nomor 05 tanggal 29 Januari Tahun 2007, Keputusan Menteri Kesehatan Republik Indonesia Nomor 907 tahun 2002, dan Peraturan Menteri Kesehatan Republik Indonesia Nomor 492 tahun 2010.

Secara definitif membran memiliki arti sebagai lapisan tipis yang berada di antara dua fasa dan berfungsi sebagai pemisah yang selektif. Pemisahan pada membran bekerja berdasarkan perbedaan koefisien difusi, perbedaan potensial listrik, perbedaan tekanan, atau perbedaan konsentrasi (Wenten, 2004). Proses membran mikrofiltrasi (MF), ultrafiltrasi (UF), reverse osmosis (RO), dan piezodialisis menggunakan perbedaan tekanan sebagai gaya dorong (driving force). Proses membran lainnya menggunakan perbedaan konsentrasi (pemisahan gas, pervaporasi, membran cair, dialisis), perbedaan suhu (membran distilasi, termo-osmosis), dan perbedaan potensial listrik (elektrodialisis) sebagai gaya dorongnya. Sebagai salah satu teknik pemisahan, teknologi membran dalam aplikasinya dapat ditujukan untuk pemekatan, pemurnian, fraksionasi, dan perantara reaksi (Mulder, 1996).

Membran ultrafiltrasi merupakan salah satu jenis membran filtrasi yang mampu memisahkan komponen dengan berat molekul tinggi dan rendah. Aliran umpan mengalir disepanjang permukaan membran secara tangensial dimana proses pemisahan membran ini melewatkan komponen dengan berat molekul rendah, sedangkan komponen dengan berat molekul tinggi seperti makro molekul, polisakarida, dan protein akan ditahan. Hal ini terjadi karena jenis membran ini termasuk berpori. Namun, struktur membrannya lebih asimetris bila dibandingkan dengan jenis membran lainnya seperti mikrofiltrasi. Pada umumnya membran ultrafiltrasi digunakan untuk pemisahan makromolekul dan koloid dalam suatu larutan atau lebih tepatnya memisahkan partikel dengan ukuran pori berkisar 0,01 mikrometer sampai 1 nanometer sehingga mampu diaplikasi secara cukup luas khususnya pengolahan air untuk menghilangkan kekeruhan, padatan tersuspensi, bakteri coliform, cryptosporidium oocysts, algae, giardia lamblia cycts, pyrogens, dan viruses (Madaeni, 1999; Lerch dkk, 2005). Proses membran ultrafiltrasi telah lama diaplikasikan dalam bidang medis untuk menyisihkan bakteri dan virus. Saat ini, desain terbaru modul hollow fiber ultrafiltrasi memungkinkan pengolahan yang ekonomis untuk mengolah air tambak. Membran ultrafiltrasi hollow fiber dapat menghilangkan hampir $100 \%$ koloid, virus, bakteri, dan material partikulat penyebab kekeruhan namun di sisi lain tetap mampu melewatkan mineral (Wenten, 2004). Saat ini, proses membran dengan tekanan gaya dorong telah tampil sebagai alternatif pengolahan air minum untuk penyisihan bahan organik alami yang terdapat dalam air (Lee dkk, 2004; Lee dkk, 2001; Yuan dan Zidney, 1999)

Berdasarkan Mirwan, dkk (2009) teknologi membran ultrafiltarsi yang diterapkan di Desa Aluh Aluh Besar Kecamatan Aluh Aluh mampu menurunkan kekeruhan air sungai sampai 2 NTU, TDS $51 \mathrm{mg} / \mathrm{L}, \mathrm{pH}$ 6,09 , kandungan mangan $(\mathrm{Mn})<0,1 \mathrm{mg} / \mathrm{L}$, dan besi (Fe) $0,13 \mathrm{mg} / \mathrm{L}$. Kondisi ini memberikan gambaran bahwa kehadiran teknologi membran ultrafiltrasi ini sangat membantu masyarakat dalam memenuhi kebutuhan air bersih yang layak konsumsi dengan kualitas air bersih yang dihasilkan memenuhi baku mutu yang disyaratkan. Namun teknologi yang diterapkan memiliki kelemahan tidak praktis dan tidak bisa dipindah-tempatkan.

Kegiatan ini bertujuan menerapkan teknologi membran ultrafiltrasi termodifikasi untuk menghasilkan air bersih layak konsumsi bagi masyarakat Desa Jambu Burung.

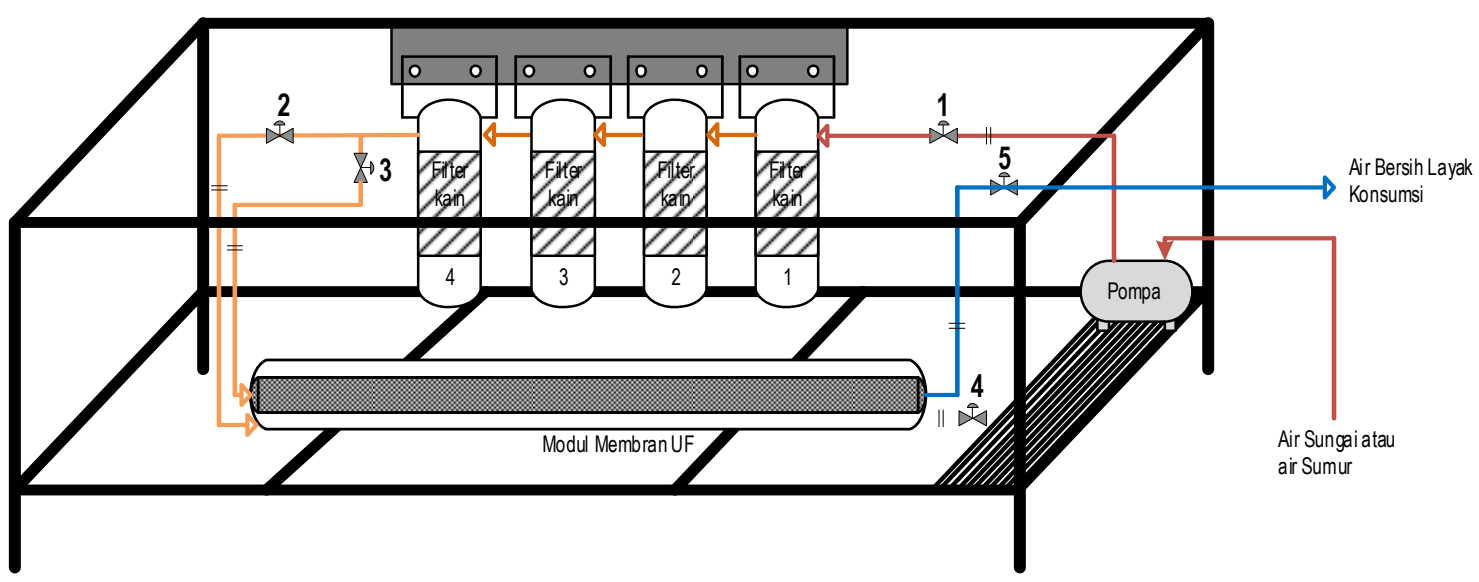

Gambar 1 Unit teknologi membran ultrafiltrasi termodifikasi 


\section{Metode}

Berdasarkan analisis situasi dan permasalahan yang dihadapi, maka kegiatan ini diarahkan untuk menerapkan teknologi pengolahan air bersih layak konsumsi yang sangat bermanfaat bagi masyarakat, terutama masyarakat Desa Jambu Burung Kecamatan Beruntung Baru Kabupaten Banjar, Kalimantan Selatan. Teknologi membran ultrafiltrasi termodifikasi yang dipilih berdasarkan pertimbangan karena memiliki beberapa keunggulan dibandingkan teknologi konvensional diantaranya mampu memisahkan spesi kimia secara spesifik, beroperasi pada suhu rendah (ambient), prosesnya tidak destruktif, hemat energi, tidak mencemari lingkungan, sederhana, praktis, mudah dioperasikan (Ibrahim dkk, 2011), dan mudah dipindah-tempatkan (mobile).Gambaran teknologi membran ultrafiltrasi termodifikasi berjenis hollow fibre UF membrane 0,01 $\mu \mathrm{m}$ ditunjukkan pada Gambar 1.

Peralatan teknologi membran ultrafiltrasi termodifikasi terdiri dari modul membran ultrafiltrasi, pompa, filter awal berbahan kain, pipa pvc ukuran 0,5 in, stop valve, dan rangka besi dengan dimensi $160 \mathrm{~cm} \times 40 \mathrm{~cm} \times 70 \mathrm{~cm}$, serta dirancang agar mudah dipindah-tempatkan (mobile). Hal tersebut didasarkan pada kondisi tempat tinggal masyarakat yang saling berjauhan.

Prosedur penggunaan rangkaian alat ini terdiri dari dua proses, yaitu proses filtrasi untuk menghasilkan air bersih layak konsumsi dan proses pencucian balik (back wash) modul membran untuk menghilangkan kotoran yang berada dipermukaan membran agar memiliki umur pemakaian yang lama. Pada proses filtrasi, air umpan berupa air sungai atau air sumur dialirkan dengan pompa untuk dilewatkan ke empat buah filter awal dan selanjutnya dialirkan ke modul membran ultrafiltrasi sehingga secara langsung diperoleh air bersih yang layak konsumsi. Proses ini berlangsung hingga fluk air bersih yang dihasilkan tetap konstan. Sedangkan proses pencucian balik dilakukan dengan mengalirkan air bersih yang dihasil melalui proses filtrasi agar kotoran atau partikel-partikel padatan yang menempel dipermukaan modul membran dapat terlepas dan hilang akibat adanya dorongan air bersih dari dalam modul membran.

\section{Hasil Kerja}

Analisis kualitas air bersih layak konsumsi yang dihasilkan melalui proses membran ultrafiltrasi termodifikasi meliputi parameter fisika (bau, total zat padat terlarut (TDS), kekeruhan, warna, suhu, daya hantar listrik (DHL)) dan parameter kimia (kesadahan $\left(\mathrm{CaCO}_{3}\right), \mathrm{pH}$, zat organik $\left(\mathrm{KMnO}_{4}\right)$, dan total fosfat-P) seperti yang ditunjukan pada Tabel 1. Hasil tersebut menunjukan penurunan yang signifikan dari hasil analisis awal untuk air sungai dan air sumur. Persen penurunan untuk masing-masing parameter tersebut menunjukkan $100 \%$ untuk $\mathrm{Fe}, \mathrm{Mn}, \mathrm{KMnO}$, total fosfat- $P$, dan total bakteri koliform. Parameter lainnya seperti TDS, kekeruhan, warna, dan DHL menunjukkan persen penurunan masing-masing sebesar $80,77 \%, 98,19 \%$, $91,62 \%$, dan $71,55 \%$. Berdasarkan hasil analisis yang diperoleh bahwa air bersih yang dihasilkan melalui proses filtrasi dengan membran telah memenuhi baku mutu air bersih yang telah ditetapkan berdasarkan peraturan Gubernur daerah kalimantan Selatan dan Keputusan Menteri Kesehatan Republik Indonesia No.907/MENKES/SK/VII/2002 tahun 2002.

\section{Kesimpulan}

Beberapa kesimpulan yang diperoleh dari kegiatan ini adalah kehadiran teknologi pengolahan air sungai dan

Tabel 1 Hasil analisis kualitas air sebelum dan sesudah melalui proses membran

\begin{tabular}{|c|c|c|c|c|c|c|}
\hline \multirow[b]{2}{*}{ Parameter } & \multirow[b]{2}{*}{ Satuan } & \multicolumn{3}{|c|}{ Hasil Analisis } & \multirow{2}{*}{$\begin{array}{c}\text { Kadar maks } \\
\text { diperboleh } \\
\text { kan }{ }^{*} \text { ) }\end{array}$} & \multirow[b]{2}{*}{ Spesifikasi Metode } \\
\hline & & Sungai & Sumur & $\begin{array}{l}\text { Proses } \\
\text { Membran }\end{array}$ & & \\
\hline \multicolumn{7}{|l|}{ FISIKA } \\
\hline Bau & - & $\begin{array}{c}\text { Tidak } \\
\text { berbau }\end{array}$ & Bau & $\begin{array}{l}\text { Tidak } \\
\text { berbau }\end{array}$ & $\begin{array}{c}\text { Tidak } \\
\text { berbau }\end{array}$ & Organoleptik \\
\hline $\begin{array}{l}\text { Total zat padat terlarut } \\
\text { (TDS) }\end{array}$ & $\mathrm{mg} / \mathrm{L}$ & 614,0 & 576,0 & 112 & 500 & SNI 06-6989.3-2004 \\
\hline Kekeruhan & NTU & 135 & 86,5 & 2 & 5 & SNI 06-2413-1991 \\
\hline Warna & $\mathrm{TCu}$ & 0,2041 & 0,1182 & 0,0135 & 50 & Spec-Ptco \\
\hline Suhu & ${ }^{\circ} \mathrm{C}$ & 27,8 & 28,7 & 27,2 & $\begin{array}{l}\text { suhu udara } \\
\pm 3^{\circ} \mathrm{C}\end{array}$ & IKM-5.4.1020 \\
\hline Daya Hantar Listrik & $\mu \mathrm{s} / \mathrm{cm}$ & 284 & 440 & 103 & - & SNI $06-6989.1-2004$ \\
\hline \multicolumn{7}{|l|}{ KIMIA } \\
\hline Kesadahan $\left(\mathrm{CaCO}_{3}\right)$ & $\mathrm{mg} / \mathrm{L}$ & 120,24 & 446,43 & 0 & 500 & SNI 06-6989.12-2004 \\
\hline $\mathrm{pH}$ & - & 7,79 & 6,11 & 6,74 & $6,5-9.0$ & IKM-5.4.1021 \\
\hline $\mathrm{Fe}$ & $\mathrm{mg} / \mathrm{L}$ & 1,40 & 2,42 & 0 & 0,3 & SNI 06-6989.4-2004 \\
\hline $\mathrm{Mn}$ & $\mathrm{mg} / \mathrm{L}$ & 0,66 & 0,74 & 0 & 0,1 & SNI 06-6989.12-2004 \\
\hline $\mathrm{KMnO}_{4}$ & $\mathrm{mg} / \mathrm{L}$ & 55,99 & 39,16 & 0 & 10 & SNI 06-6989.22-2004 \\
\hline Total Fosfat-P & $\mathrm{mg} / \mathrm{L}$ & 0,427 & 0,121 & 0 & 0,2 & Spect-PMB \\
\hline \multicolumn{7}{|l|}{ BIOLOGI } \\
\hline Total Bakteri Koliform & $\begin{array}{c}\text { Jumlah per } \\
100 \mathrm{ml} \\
\text { sampel }\end{array}$ & 2400 & 1300 & 0 & 0 & \\
\hline
\end{tabular}


air sumur menjadi air bersih layak konsumsi menggunakan membran ultrafiltrasi termodifikasi sangat membantu masyarakat Desa Jambu Burung sehingga tumbuh kesadaran masyarakat akan pentingnya air bersih. Kualitas air bersih yang dihasilkan telah memenuhi baku mutu air bersih yang telah ditetapkan dengan parameter fisika dan kimia menunjukkan tidak ada bau, total zat padat terlarut (TDS) sebesar $112 \mathrm{mg} / \mathrm{L}$, kekeruhan $2 \mathrm{NTU}$, warna $0,0135 \mathrm{TCu}$, suhu $27,2^{\circ} \mathrm{C}$, daya hantar listrik $103 \mu \mathrm{s} / \mathrm{cm}$, $\mathrm{pH} 6,74$. Lebih lanjut kesadahan, besi, mangan, zat organik, dan total fosfat, serta total bakteri koliform menunjukkan angka nol.

\section{Ucapan Terimakasih}

Kegiatan ini dibiayai oleh Direktorat Penelitian dan Pengabdian kepada Masyarakat Direktorat Jenderal Pendidikan Tinggi Kementerian Pendidikan dan Kebuadayaan sesuai dengan Surat Perjanjian Pelaksanaan Penugasan Program Pengabdian kepada Masyarakat Nomor 009 / SP2H / KPM / DIT.LITABMAS / V / 2013 tanggal 13 Mei 2013.

\section{Referensi}

Ibrahim, S. Mirwan, A. Wicakso, D.R. 2011. IbM Desa Kelampayan Tengah untuk Penyediaan Air yang Layak Konsumsi, Banjarbaru, Laporan Pengabdian kepada Masyarakat Program Ipteks bagi Masyarakat ( $\left.{ }_{b} M\right)$. Universitas Lambung Mangkurat Banjarmasin.

Keputusan Menteri Kesehatan Republik Indonesia No.907. 2002. tentang syarat-syarat dan pengawasan kualitas air minum. Kementerian Kesehatan Republik Indonesia Jakarta.

Lee, H., G. Amy, J. Cho, Y. Yoon, S-H. Moon, and I.S. Kim. 2001., Cleaning Strategies for Flux Recovery of an Ultrafiltration Membrane Fouled by Natural Organic Matter, Journal Water Research. 35 (14): 3301-3308.
Lee, N., G. Amy, J-P. Croue, and H. Buisson. 2004. Identifikation and Understanding of Fouling in LowPressure Membrane (MF/UF) Filtration by Organic Matter, Journal Water Research. 38: 4511-4523.

Lerch, A. S. Panglisch, P. Buchta, Y. Tomita, H. Yonekawa, K. Hattori and R. Gimbel. 2005. Direct river water treatment using coagulation/ceramic membrane microfiltration. Desalination Journal. 179.(1-3): 41-50.

Madaeni, S. 1999. The application of membrane technology for water desinfection. Water Research. 33 (2): 301-308.

Mirwan, A. Rafiedz, F. Mursyidin, DH. 2009. Penerapan Teknologi Membran Ultrafiltrasi dalam Penyediaan air Bersih Bagi Masyarakat Aluh Aluh Kalimantan Selatan, Laporan Pengabdian Kepada Masyarakat. Universitas Lambung Mangkurat. Banjarbaru.

Mulder, M., Basic Principles of Membrane Technology. 2nd ed. 1996, Netherlands: Kluwer Academic Publisher.

Peraturan Gubernur No 05. 2007. tentang peruntukan dan baku mutu air sungai. Bapedalda Propinsi Kalimantan Selatan

Susanto, B. 2009. Kajian Kualitas Air Sungai yang Melewati Kecamatan Gambut dan Aluh Aluh Kabupaten Banjar Kalimantan Selatan. Skeripsi. Fakultas MIPA Universitas Lambung Mangkurat. Banjarbaru.

Wenten, I. G. 2004. Teknologi Membran dalam Pengolahan Air dan Limbah Industri. Studi Kasus: Pemanfaatan Ultrafiltrasi untuk Pengolahan Air Tambak.

Yuan, W., L. Zydney,. 1999. Humic Acid Fouling During Microfiltration, Journal of Membrane Science. 157: 112. 